recommendations then go forward to ACDA Secretary at the Common Services Agency in Edinburgh together with citation forms which are prepared by a member of the Scottish Division Merit Awards Committee. The Chairman also informs the President of the
College of the nominations of the Scottish Division.

R. G. McCreadie, Chairman, Scottish Division, Royal College of Psychiatrists, 9 Queen Street, Edinburgh EH2 1JQ

\title{
Distinction Awards: how the Northern Ireland scheme is organised
}

The scheme is based on a system of peer review and is controlled by the Distinction and Meritorious Service Awards Committee. The DMSAC advises the Department which consultants engaged in the Health Service should receive awards for professional distinction and in so doing seeks to ensure that no consultant who has been nominated from whatever source fails to receive fair consideration and that the purpose behind the scheme is being fulfilled.

The Committee is appointed by the Head of the Department of Health and Social Services with the concurrence of the relevant Minister. Members are appointed in the first instance for three years on a rotational basis, with provision for re-appointment for a second term.

Vacancies occur at the end of each year when the Committee is reconstituted. The current membership is:

Chairman Mr D. S. Gordon CBE

\author{
Members Professor J. W. Dundee OBE \\ Professor J. E. Cooper \\ Professor M. McGeown CBE \\ Professor B. M. Hibbard \\ Professor M. Rosen CBE \\ The Rt Hon Lord Justice \\ O'Donnell QC \\ Mr P. G. Kinder CBE
}

Of these members, three are consultants from Great Britain appointed with a view to ensuring parity of standards throughout the United Kingdom, three are retired consultants from Northern Ireland who are of such standing as to have no personal interest in the allocation of awards. Of the remaining members one is the General Manager of the Eastern Health and Social Services Board while the other is a retired Lord Justice of Appeal of the Supreme Court whose role is to ensure that consistent standards are maintained. 